\title{
Using visual analysis in tourism attraction management of puncak menara api gunung Saribu village, Munte district, Karo regency
}

\author{
Junita Setiana Ginting ${ }^{1 *}$, Rudy Sofyan ${ }^{1}$, Samerdanta Sinulingga ${ }^{1}$ \\ ${ }^{1}$ Faculty of Cultural Sciences, Universitas Sumatera Utara, Medan, Indonesia \\ Email*: irfanberbagi@gmail.com
}

\begin{abstract}
Puncak Menara Api in Gunung Saribu Village, Munte Sub-District, Karo Regency, is a buffer zone of the protected forest area in Karo Regency. In 2020, all the local communities through village funds are trying to pioneer the development of Puncak Menara Api as a new tourist attraction. In relation to such an effort, the community service team of Universitas Sumatera Utara assisted the people in Gunung Saribu Village in creating the concept of developing Puncak Menara Api as a nature-based and education-based tourist attraction in Karo Regency. The assistance includes but not limited to improving the capacity of tourism management for rural communities, mapping the tourist sites, marketing the tourist sites, and so forth. For the many development activities items that must be done, the team selected mapping tourist sites as the only activity to be carried out in 2020 . This study was conducted using a qualitative method. The data were collected using focus group discussion, observation, and interview techniques. The data were analyzed using visual analysis, including visualizing the point object attributes, visualizing point object distribution, and visualizing spatial groupings. The results of the study are: (i) the visualization on the point object attributes finds four main components related to tourism: Attractions, Accessibility, Amenities, and Ancillary Services; (ii) the visualization on the point object distribution results in predicting the initial picture of the arrangement of tourist attractions in Puncak Menara Api; and (iii) the visualization on the spatial groupings results in designing the tourist location in a three-dimensional design.
\end{abstract}

\section{Keywords: tourist village, the arrangement of tourist attractions, visual analysis}

\section{Introduction}

On the 73rd anniversary of the Karo Regency on March 8, 2019, the Karo District Government officially introduced a new tourism asset belong to the region. The tourist destination is located in Menara Api in Gunung Saribu Village, Munte Sub-District. The local people call it Puncak Menara Api (Fire Tower Peak). The name is derived from the name of a tower built on the peak of the hill in the 1970s. The tower was used to monitor hotspots in Karo Regency. From the peak, people can see a view of three mountains in Karo Regency, namely Mount Sinabung, Mount Sibayak, and Mount Barus. In addition, between Mount Barus and Mount Sibayak people can see Deleng Kutu Hill. Currently, the Karo Regency Government has begun addressing Deleng Kutu Hill as the Tourism Development Program. This certainly leads to the question concerning the ideal development model and the structuring concept for the program.

Examined from its regional background, Puncak Menara Api is a buffer zone of a protected forest area in the Karo Regency. It is called a buffer zone because it is the outermost point of the core zone of the forest conservation area (Liu, Ouyang, \& Miao, 2010). This buffer 
zone is an area with very complex problems because it often becomes a source of conflict due to a conflict of interests between the conservation's needs and the local people's needs (Gunawan, Bismark, \& Krisnawati, 2013). Therefore, the development of buffer zone needs high accuracy in any sector of development because inaccurate development of a tourism model in the buffer zone area can result in the loss of conservation values whose main purpose is for environmental preservation (Jüttner, Galla, \& Schmieder, 2000; Shen \& Tan, 2012; Naseem, Hussain, \& Munir, 2016). Besides, it can destroy the biodiversity contained in the area because destructive effects are generally diffuse (Sunlu, 2003; Urbanus \& Febianti, 2017).

After the community service team had conducted direct interviews with the local people and village officials, they discovered a phenomenon of the willingness of people in Gunung Saribu Village to start and open a new tourist destination that could become an opportunity for the local people to promote their village. In pioneering and creating new tourist locations, many future challenges will certainly be encountered by the local people (Chang, Chien, Cheng, \& Chen, 2018). Therefore, the community service team as academicians will then serve themselves as the consultants for the people of Gunung Saribu Village in achieving their dream of making Puncak Menara Api a new tourist location in Karo Regency in the future.

To successfully make Puncak Menara Api a new tourist location in Karo Regency, there must be several feasibility tests on the concept of regional arrangement that can be implemented; so the development process will not harm the local people in the future. Several studies have reported the negative effect on the local people. Abdillah, Hamid, and Topowijono (2016) argue that the development of tourist attractions has either a direct or indirect effect on the local environment. In a more detailed description, Ghobadi and Verdian (2016) found that the development of tourist attractions has several serious effects associated with air, water, sound pollutions, waste accumulation, and environmental pollutions. They even believe that if these pollutions continue to occur they may result in irreparable damages. In addition, Urbanus and Febianti (2017) report that the development of tourist attractions in Bali affects water source availability. Therefore, it is necessary to have a visualization of the location which can be an illustration of when construction will be carried out in the future. From the problems elaborated above, this study aims at arranging tourist attraction in Puncak Menara Api, in Gunung Saribu Village, Munte District, Karo Regency, using visual analysis.

\section{Method}

This study was conducted used a qualitative method, employing phenomenology and spatial science including space and time as the approach. The subject of this study was major stakeholders, the stakeholders who have direct interests in Gunung Saribu Village, Munte SubDistrict, Karo Regency. The sample was selected using a snowball sampling technique. The sources of data were both primary and secondary data sources. The primary data source was interviews with informants, and the secondary data source was digital information, e-books, books, laws, and films/photos. The research instruments were interview guidelines and film format manuals. The observation was conducted using participant observation. The data were analyzed using the interactive model of data analysis proposed by Miles, Huberman, and Saldana (2014) that included data condensation, data display, conclusion/verification.

\section{Results and Discussion}

\subsection{Visualization of Point Object Attributes}

In the visualization of point object attributes, the community service team conducted an inventory of the basic components of tourism elements, including attraction, accessibility, amenity, and ancillary service (Camilleri, 2017). The first component, tourist attraction, 
contains three basic elements: natural, cultural, and man-made attractions. Nevertheless, the results of the data analysis show that there are only two basic elements of tourist attractions found in Gunung Saribu Village: natural tourism and cultural tourism. In terms of nature tourism, Gunung Saribu Village has several potentials for natural tourism, including forests and their various wildlife (such as primates, wild boar, and other wild animals), wide natural panoramas of hills, rivers, and cool weather. Meanwhile, in terms of cultural tourism, the potentials of cultural attractions in Gunung Saribu Village are people's agricultural land (such as rice fields, tobacco fields, corn, and dragon fruit gardens), local people's activities reflecting naturally rural nuances, and people's bee farms.

The second component, tourist accessibility, has several elements, such as access, mobility, and mileage (La Rocca, 2015). Gunung Saribu village has narrow road access and is mostly dominated by rocky agricultural road access. The road surface in some parts of the village is asphalt and in some other parts is soil. With such access to the location, motorbikes are widely used by the people. If the rainfall is high, the use of four-wheel vehicles to the location has not been recommended until the present time because the road surface is slippery and very loose. If the point of mobility is determined from Medan City, the density of transportation occurs during holidays, vacations, and big market days. During these days, the challenges faced to get to the location start when approaching the village, due to the narrow roads and bends with very limited viewpoints. The traveling time from Kabanjahe City to the location only takes about 30 minutes and or about 2 hours 40 minutes from Medan City.

The third component, amenity, is the facility to support tourism activities such as accommodation, restaurants, souvenir shops, and proper bathrooms. Until now, from the data that have been collected, the facilities available in Gunung Saribu Village have minimal completeness and the local people have a low capability in supporting the tourism activities. Most of them have never been involved in tourism activities at all. Due to the low level of community involvement, the facilities supporting the tourism activities are very limited as well. Such a condition certainly affects the ancillary service. Additional facilities such as cafes, shelters, and other complementary facilities are not available in Gunung Saribu Village. However, if those facilities, both main and supporting facilities, are built, the local people will have great enthusiasm and willingness to give their land for such facilities constructions. Thus, the existence of facilities will support the development of tourist attractions in this village.

After the data inventory was carried out, the community service team then determined the location coordinates. This is particularly important to prepare the right location for tourist attraction development in Gunung Saribu Village. To determine the location coordinates, the community service team used the GPS Map Camera application as displayed in Figure 1. 


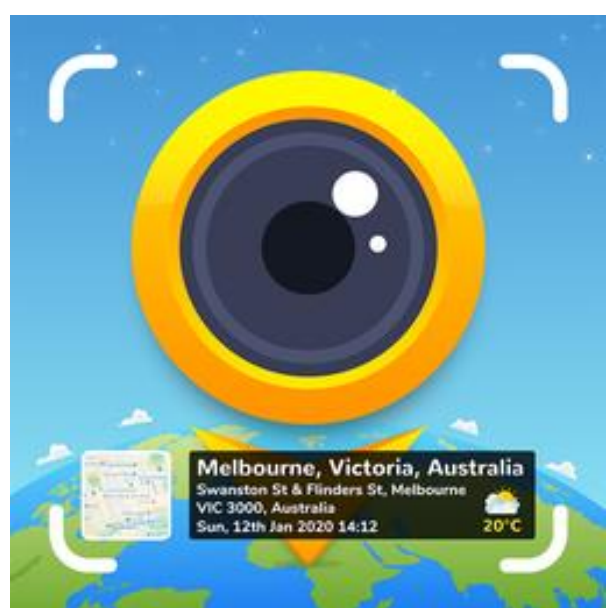

Figure 1. GPS Map Camera application

By using the GPS Map Camera application, the location coordinates of Puncak Menara Api in Gunung Saribu Village are obtained as shown in Figure 2.

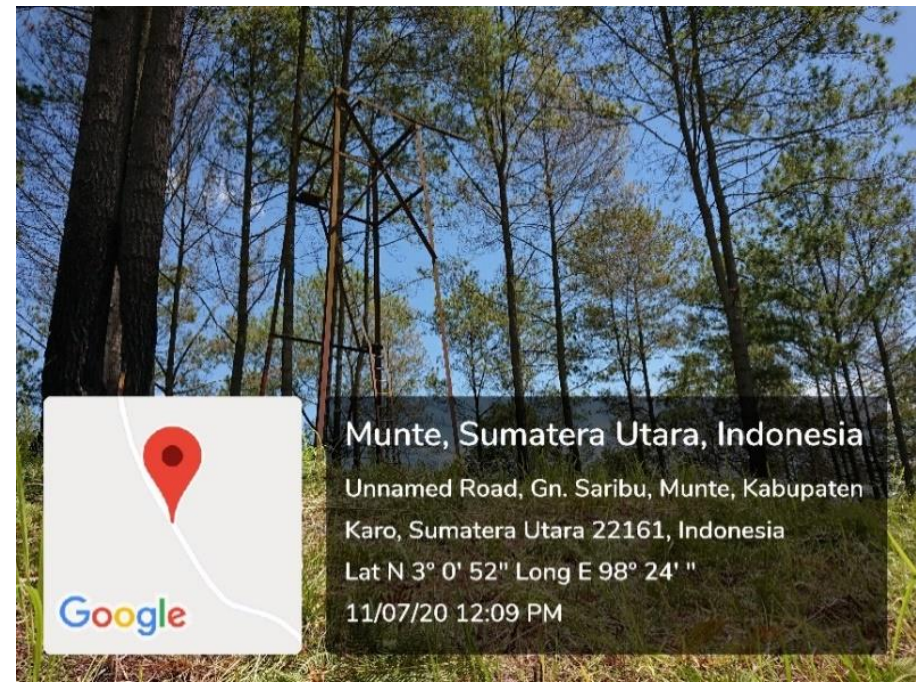

Figure 2. The location coordinates of Puncak Menara Api in Gunung Saribu Village

Based on the information available in Figure 2, Puncak Menara Api is located in Gunung Saribu Village, Munte Sub-District, Karo Regency, North Sumatra Province, Indonesia. Its latitude is N $3^{\circ} 0^{\prime}$ '52", while its longitude is E $98^{\circ} 24^{\prime \prime}$.

\subsection{Visualization of Point Object Distribution}

Visualization of the point object distribution is carried out after the analysis of the inventory of attractions, accessibility, amenities, and ancillary services. Based on the variety of data collected, the preliminary design for the construction of a tourist site in Puncak Menara Api in Gunung Saribu Village is made as shown in Figure 3. 
Junita Setiana Ginting et.al. Using visual analysis in tourism attraction management

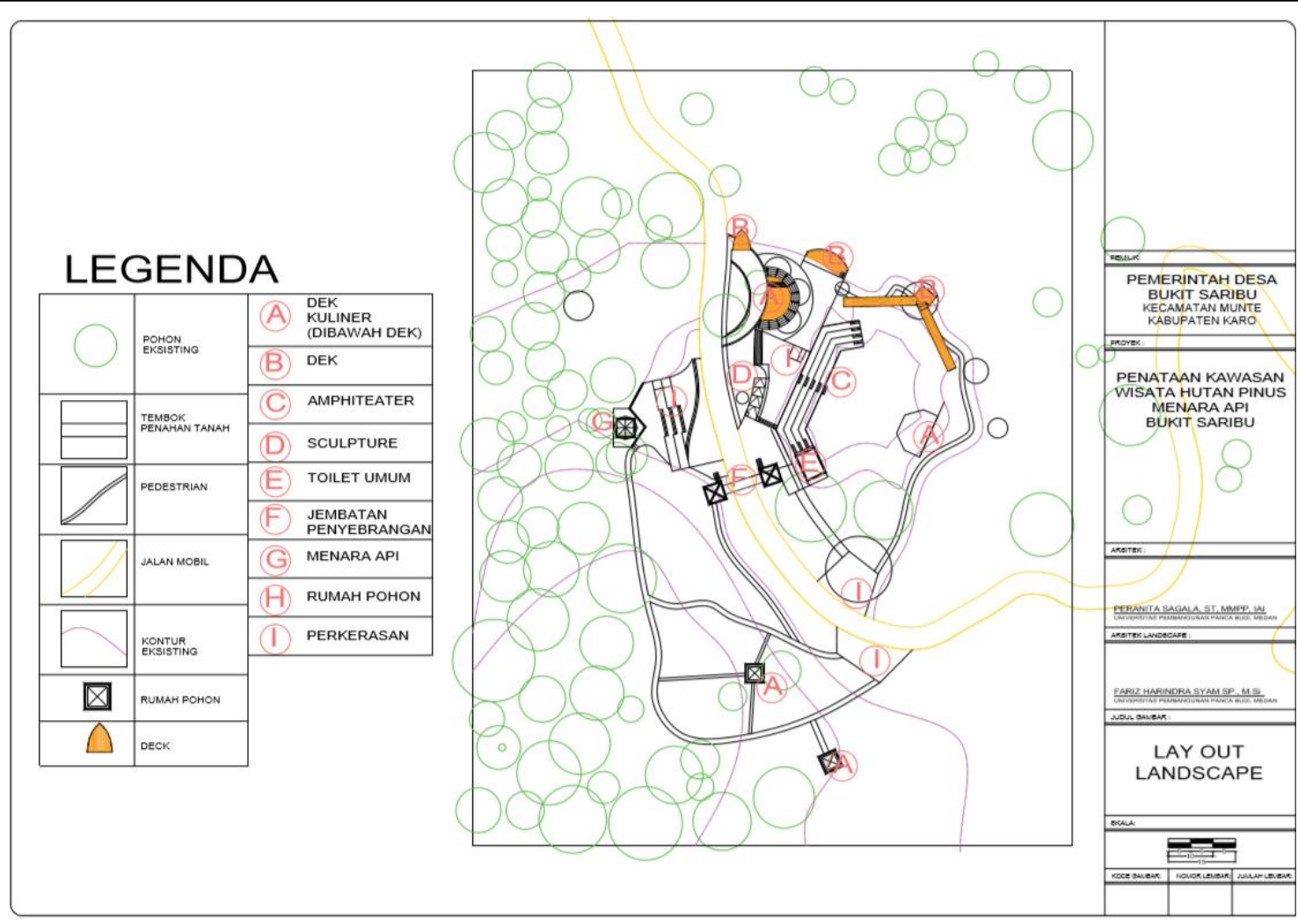

Figure 3. Preliminary design for the construction of a tourist site in Puncak Menara Api

The preliminary design in Figure 3 shows several locations that have been selected as the places to build the main and supporting facilities. The existence of those facilities is expected to realize the desire of the local people and the local government to make Puncak Menara Api a promising tourist attraction in Gunung Saribu Village, Munte Sub-District, Karo Regency.

\subsection{Visualization of Spatial Grouping}

The analysis of spatial grouping is used to determine the group of spaces in which the facilities will be built. Every facility should be designed as interesting as possible together with the place where each of them will be built. Based on the results of data analysis through spatial grouping visualization, a pictorial design of the facilities in the tourist site Puncak Menara Api is made as shown in Figure 4. 


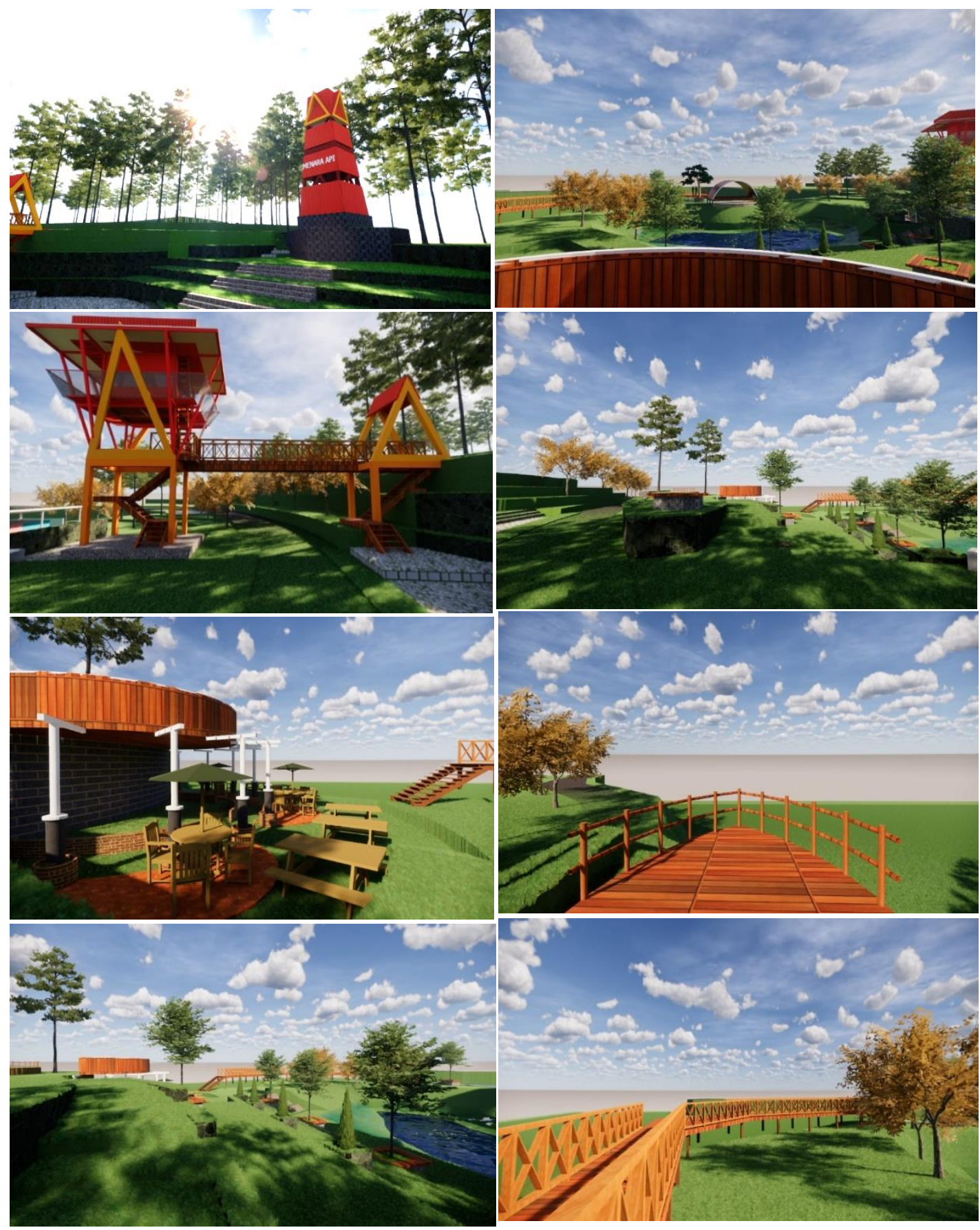

Figure 4. A pictorial design of the facilities in the tourist site Puncak Menara Api

The first picture in the pictorial design (a three-dimensional design) in Figure 4 is a "welcome" monument. This is very important to show the local people's friendliness to all visitors coming to Puncak Menara Api. As this is the first construction in the tourist site that will be seen by visitors, it should be well-designed. The shape, the color, and the accompaniment construction around the monument should reflect the attractiveness of the site. The same design also applies to other facilities, such as bridges, parks, shelters, pools, and others.

Based on the facilities illustrated in the three-dimensional design displayed in Figure 4, it is expected that the concept of nature-based and education-based Puncak Menara Api tourist 
Junita Setiana Ginting et.al. Using visual analysis in tourism attraction management

site can be achieved. Green grass, trees, and flowers are shown in the design reflect the naturebased tourist site.

\section{CONCLUSIONS AND SUGGESTIONS}

Puncak Menara Api is located in Gunung Saribu Village, Munte Sub-District, Karo Regency. It is a very beautiful place, but its beauty is not well managed. The local people's desire to develop this place as a tourist site is hampered due to very limited facilities and their low experience in tourism activities. Nevertheless, their desire has some positive responses from many parties, including the community service team of Universitas Sumatera Utara. They committed to take a part in developing this area through some assistance. At this stage, they have designed the preliminary model of development of Puncak Menara Api as a tourist attraction. They have made a pictorial design illustrating the facilities that need to be built to support the tourist attraction in Puncak Menara Api. The preliminary design made by the community service team is expected to be a reference for other similar future studies. There are many other places in North Sumatra, in particular, that have the potentials to be developed as a tourist site. Therefore, it is suggested to other researchers to conduct a study on tourist attraction development in other places.

\section{REFERENCES}

Abdillah, A. B. Y., Hamid, D., \& Topowijono (2016). Dampak pengembangan pariwisata terhadap kehidupan masyarakat lokal di kawasan wisata (Studi pada masyarakat sekitar wisata Wendit, Kabupaten Malang). Jurnal Administrasi Bisnis (JAB), 30(1), 74-78.

Camilleri, M. (2017). The tourism industry: An overview. In Camilleri, M. (Ed.), Travel marketing, tourism economics and the airline product (pp 3-27). Milan: Springer.

Chang, K. G., Chien, H., Cheng, H., \& Chen H-i. (2018). The impacts of tourism development in rural indigenous destinations: An investigation of the local residents' perception using choice modeling. sustainability, 10, 47-66.

Ghobadi, G. J. \& Verdian, M. S. (2016). The environmental effects of tourism development in Noushahr. Open Journal of Ecology, 6, 529-536.

Gunawan, H., Bismark, M., \& Krisnawati, H. (2013). Kajian sosial ekonomi masyarakat sekitar sebagai dasar penetapan tipe penyangga Taman Nasional Gunung Merbabu, Jawa Tengah. Jurnal Penelitian Hutan dan Konservasi Alam, 10(2), 103-119.

Jüttner, K., Galla, U., \& Schmieder, H. (2000). Electrochemical approaches to environmental problems in the process industry. Electrochimica Acta. 45(15), 2575-2594.

La Rocca, R. A. (2015). Tourism and mobility. best practices and conditions to improve urban livability. TeMA - Journal of Land Use, Mobility and Environment, 8(3), 311-330.

Liu, J., Ouyang, Z., \& Miao, H. (2010). Environmental attitudes of stakeholders and their perceptions regarding protected area community conflicts: A case study in China. Journal of Environmental Management, 91(11), 2254-2262.

Miles, M. B, A. Huberman, M., \& Saldana, J. (2014). Qualitative data analysis: A methods sourcebook $\left(3^{\text {rd }}\right.$ ed.). Thousand Oaks, CA: Sage Publications, Inc. 
Junita Setiana Ginting et.al. Using visual analysis in tourism attraction management

Naseem, S., Hussain, M., \& Munir, T. (2016). Environmental protection for biological conservation: A review. Journal of Entomology and Zoology Studies, 4(4), 561-564.

Shen, X. \& Tan, J. (2012). Ecological conservation, cultural preservation, and a bridge between: The journey of Shanshui Conservation Center in the Sanjiangyuan Region, Qinghai-Tibetan Plateau, China. Ecology and Society, 17(4), 1-10.

Sunlu, U. (2003). Environmental impacts of tourism. In Camarda, D., \& Grassini, L. (eds.), Local resources and global trades: Environments and agriculture in the Mediterranean region (pp. 263-270). Bari: CIHEAM.

Urbanus, I-N. \& Febianti. (2017). Analisis dampak perkembangan pariwisata terhadap perilaku konsumtif masyarakat wilayah Bali Selatan. Jurnal Kepariwisataan dan Hospitalitas, $1(2), 118-133$. 